\title{
Between Mobility and Connectivity in the Ancient Mediterranean
}

\author{
Coast-Skirting Travellers in the Southern Levant
}

Gil Gambash

Connectivity and Mobility

Forces of sea-bound connectivity in antiquity are believed nowadays to have been strong enough to overcome geographical barriers and unfavourable natural conditions; as well as to cross boundary lines once thought impenetrablebe it of cultural, political, or religious nature. ${ }^{1}$ And, within the sphere of connectivity, coastal seafaring - also referred to in professional literature as cabotage - gradually reveals itself to have been enduring, and to have functioned continuously, regardless of shifting circumstances. It is now considered by modern scholarship as one of the key agents of connectivity. The focus of the study of maritime activity in the ancient Mediterranean has thus shifted from large freighters, carrying high-value commodities from one major port to another along sea-crossing routes, to smaller vessels, operating locally, mostly along the coast, while servicing trade in elementary goods.

This understanding may have significant implications for the topic of this volume-particularly with regard to issues of mobility and empire-but not necessarily in the way that appears the most obvious. Direct links have often been drawn between Mediterranean connectivity and actual maritime mobility, to the effect that the two terms often seem to overlap in current discourse. But if, like commerce, much of mobility relied on cabotage, grave difficulties and limitations would have been imposed on travellers - certainly those who

1 Geniza documents have been famously shown by S.D. Goitein, A Mediterranean Society: The Jewish Communities of the Arab World as Portrayed in the Documents of the Cairo Geniza (Berkeley and Los Angeles 1967-1993) to disprove notions of a Muslim-Christian divide across the Mediterranean, as previously perceived by H. Pirenne, Mahomet et Charlemagne (Paris 1937). Theories of connectivity have reached their culmination with the publication of P. Horden and N. Purcell, The Corrupting Sea: A Study of Mediterranean History (Oxford 2000), $123-172$. 
crossed micro-regional boundaries. This assertion must also have implications for the imagined volume of passenger traffic in the Roman Mediterranean. ${ }^{2}$

Let us first be reminded of several conventions, that make up the building bricks of the idea of connectivity as we have come to perceive it in the past couple of decades: the Sea is the principal agent of connectivity; this makes the world of the Sea central, and, of necessity, leaves the terrestrial realm as marginal. This marginality increases with distance from water, to the extent that the very definition of distance may become inverted-connectedness through the Sea equals closeness, whereas the lack of interaction (even between neighbours) equals remoteness. The extent to which these assertions presume to encompass both commercial activity and human mobility is encapsulated in the following statement made by Horden and Purcell: "The main hindrance to the movements of people and goods by land has usually been social rather than physical." From this starting point, current scholarship often finds it selfevident and straightforward enough to read 'people' as 'masses of people' or even 'most people', rather than mere individuals. The movement of individuals and groups is thus depicted as omnipresent and continuous, and, most important, as varied in regard to its goals, geographical scope, and the identity and status of travellers. And this picture relies heavily on the assumed availability of maritime means of transportation.

But, to what extent can this hypothesis of omnipresent mobility be considered as compatible with the strong emphasis of our sources on cabotage? To be sure, the intensive, perennial activity of coast-skirting vessels may and should be regarded as a key player in the ancient Mediterranean economy, one that offered solutions of supply wherever and whenever demand in its various forms appeared. A picture of a dominant coast-based network, however, imposes on the actual mechanics of travelling a set of limitations that may have been overlooked in the process of generalization that has attached, all too easily, mobility to connectivity. Since most aspects of this phenomenonsave, perhaps, the average tonnage of ships-remain more or less constant throughout antiquity (and beyond), we may move freely along the temporal axis in search of relevant evidence.

2 Greg Woolf has recently risen to the challenge of offering much needed qualification and quantification to mobility in the ancient Mediterranean. His article may be read as a broader background to the focus placed here on cabotage: G. Woolf, 'Movers and stayers', in L. de Ligt and L.E. Tacoma, eds., Migration and Mobility in the Early Roman Empire (Leiden 2016), 440-463.

3 Horden and Purcell 2000, op. cit. (n. 1), 132. 
In a recent research project, for example, travelling in the late-antique west was examined through inscriptions. ${ }^{4}$ The corpus consists of 567 inscriptions recording foreigners and travellers-623 in number. 84 per cent of these people were men, mostly between the ages of 20 and 50 . A good number of them were nobles, bishops, and office holders; but also represented are sailors, soldiers, and, of course, merchants. To be sure, significant portions of the population are not represented in these lists, including individuals who the author, in the spirit of our times, assumes did travel, only without leaving their mark. In a Mediterranean world relying to a large degree on cabotage, such an assumption may not be made straightforwardly, certainly for the lower echelons of society.

\section{$2 \quad$ Mobility and Physical Danger}

In order to be reminded of just how challenging travelling by sea could be, it may prove beneficial to return to the story of one of the most famous travellers in antiquity - Paul of Tarsus. Despite the wealth of detail on travelling in Paul's story, scholarship does not easily allow a balanced appreciation of his travels, since, when evaluating Paul's achievements, it often admires the general ease of travel in Roman times-in accordance with the prevalent picture of connectivity; and when scholars set to examine Paul's suffering during his travels, which he describes elaborately on a number of occasions, they approach his suffering as part of his spiritual struggle, and not necessarily as part of the routine of travelling. ${ }^{5}$

The well-known depiction of the shipwreck of Paul, when on his way to Rome for the last time, certainly adds colour to our discussion. The dangers and difficulties that were shared by the entire travelling population of the Mediterranean, especially insofar as inclement weather was concerned, are well documented in our sources, and sufficiently noticed by modern scholarship. ${ }^{6}$ This particular aspect of travelling was shared by vessels of all sorts ploughing the Mediterranean, big or small, coastal or open-sea, especially when sailing beyond the dates of the so-called 'sailing season'—now believed

4 M.A. Handley, Dying on Foreign Shores: Travel and Mobility in the Late-Antique West (Portsmouth, R.I. 2011).

5 R.S. Schellenberg, 'Danger in the wilderness, danger at sea: Paul and the perils of travel', in P.A. Harland, ed., Travel and Religion in Antiquity (Waterloo, Ont. 2011), 123-140.

6 For a discussion of shipwreck statistics see C. Hezser, Jewish Travel in Antiquity (Tübingen 2011), 167 . 
to have been far less rigid than we once used to believe-and outside the realm of the customary lanes, mostly dictated by the regime of winds. ${ }^{7}$

Shipwreck archaeology and written sources join to supply an elaborate picture of the dangers presented by unwelcoming weather to ships making their way along the coasts of the Mediterranean. ${ }^{8}$ Indeed, this danger appears to have existed also within the relative safety of natural anchorages, and even within the sphere of the great artificial harbours. In AD 62, 200 ships were sunk by a storm in the recently inaugurated harbour of Portus, near Rome. Centuries later, Procopius of Gaza reports that the poorly maintained harbour of Caesarea Maritima was similarly betraying its main function, seeing that ships were constantly being wrecked in the harbour itself. ${ }^{9}$

To be sure, underwater archaeology is less helpful when one turns to survey the impact of the weather over ships employing open-sea routes. Above all, the written sources offer a plethora of testimonies demonstrating the obvious difficulties that such voyages encountered. Josephus, when on his way to Rome, reports: ${ }^{10}$

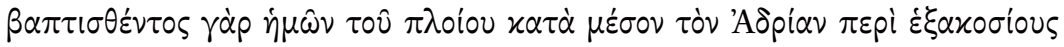

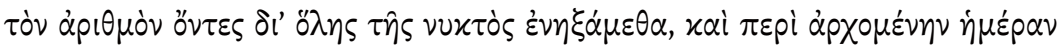

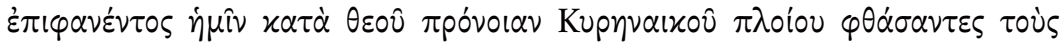

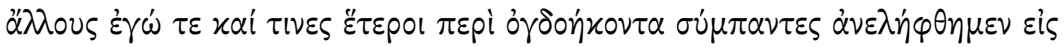
$\tau$ cò $\pi \lambda \circ \hat{\imath} \mathrm{ov}$.

As our ship was wrecked in the middle of the Adriatic Sea, being about six hundred people present aboard, we swam all night long; and upon the break of day, by God's providence, we saw a ship of Cyrene, and I and some others, about eighty altogether, outstripped the others, and were taken up into that ship.

7 Horden and Purcell 2000, op. cit. (n. 1), 137-143; J. Beresford, The Ancient Sailing Season (Leiden and Boston 2013).

8 Shipwreck stories were of course also part of storytelling repertoires, and have been studied as standardised narratives. See, for example, Schellenberg 2011, op. cit. (n. 5); B. Dunsch, 'Describe nunc tempestatem: Sea storms and shipwreck type scenes in ancient literature', in C. Thompson, ed., Shipwreck in Art and Literature: Images and Interpretations from Antiquity to the Present Day (London 2014), 42-59.

9 Tac. Ann. 15.18; Procop.Gaz. Pan. 19.

10 J. Vit. 14-16. All translations in this article are supplied by the author. 
The large size of the vessel described by Josephus is of significance, but even more interesting is the number of passengers on board, which, if reported correctly, would have made the vessel a large-scale ferry rather than the typical grain clipper, the latter usually hosting smaller numbers of travellers alongside its cargo. ${ }^{11}$

\section{$3 \quad$ Mobility and Cabotage}

One such grain clipper was the Isis, known to us from a dialogue by Lucian of Samosata, who relates: ${ }^{12}$

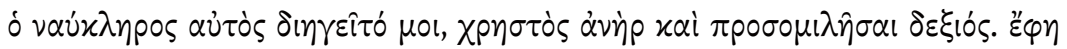

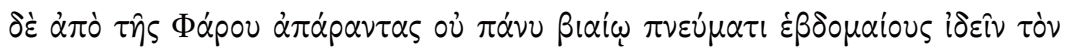

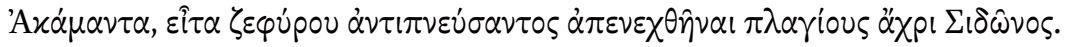

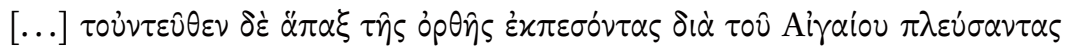

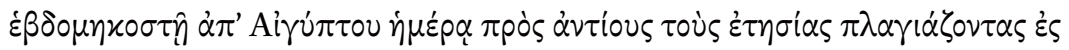

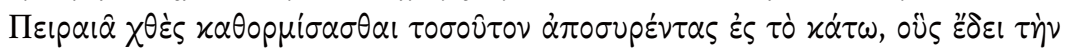

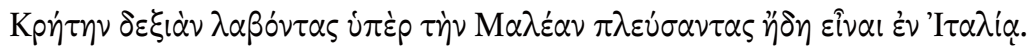

The captain himself described it to me, a nice man and good to talk to. He said that, when they left from Pharos, the wind did not blow too forcibly, and they sighted Akamas on the seventh day. Then a west wind blew against them, and they were carried east all the way to Sidon [...]. Having lost their proper course, they sailed across the Aegean against the Etesian winds, and seventy days after leaving Egypt they anchored yesterday in Piraeus, having drifted that far downwind. If they had kept Crete on their right, they would have sailed past Malea, and been in Italy by now.

11 The Nomos Rhodion Nautikos-hereafter NRN, used here after the 2001 reprint of W. Ashburner, ed., Rhodian Sea-Law (Oxford 1909) — a Byzantine Sea Law based on earlier Roman legislation, stipulates that each passenger should be allotted a deck-space of $1.875 \mathrm{~m}$. by $0.625 \mathrm{~m}$ ( $N R N 2.9)$. If abiding by such standards, the ship described by Josephus would have reached an imaginary size of $6 \mathrm{om}$. by $12 \mathrm{~m}$. - not much smaller than the gigantic ships of Lake Nemi.

12 Luc. Nav.7-9. See L. Casson, 'The Isis and her voyage', Transactions and Proceedings of the American Philological Association 81 (1950), 43-56; and G.W. Houston, 'Lucian's Navigium and the dimensions of the Isis', The American Journal of Philology 108.3 (1987), 444-450. 
Significantly, the northern Etesian winds (known today also as the Meltemia), blow in the Aegean, often strongly and durably, throughout the summer-the very time of the sailing season. To be sure, such reports emphasize the difficulties and dangers experienced also by larger ships as a result of shifty weather. Interestingly, by demonstrating the need of these ships for constant improvisation, they offer an expansion of the very sphere of cabotage as it is employed today, to include also large ships, originally headed towards large artificial harbours along fixed routes-often across the open sea. ${ }^{13}$

While, in its strict sense, cabotage refers solely to coast-skirting activityand, in effect, is still employed as such in the French-speaking academic discourse-it has come to represent for us a broader phenomenon, essentially epitomized in the great flexibility of vessels and seamen in antiquity to act beyond the limitations allegedly imposed on them by natural as well as political circumstances. ${ }^{14}$ As stated in the opening of this article, this flexibility is usually ascribed to smaller ships, and is studied through their perspective. There is no reason why we should not include also significant parts of the activity of larger ships in this sphere.

The details leading towards the shipwreck of Paul may serve well to demonstrate this point, and should be observed closely—not necessarily because they offer an authentic description of a historical event, but because they represent a plausible depiction which would have applied in cases of similar background..$^{15}$ Looking for a way to travel from Lycian Myra to Rome, the centurion escorting Paul found an Alexandrian ship sailing for Italy, and put them on board. The ship must have been significant in size and, due to its place of origin, we may easily imagine that it carried grain. No less than 276 people are said to have been on board. Though starting its way still within the sailing season, the ship encountered unwelcoming weather, and dawdled off the coasts of southwestern Asia Minor (Cnidus), and then Crete (Salmone and Lasea).

Finding themselves in a harbour in southern Crete that was not suitable for the upcoming winter, and with the last days of the sailing season now past, the owner of the ship and its pilot decided to pursue their journey, hoping at the very least to make it to the harbour at Phoenix. ${ }^{16}$ It was then that the

\footnotetext{
13 P. Arnaud, Les routes de la navigation antique: Itinéraires en Méditerranée (Paris 2005).

14 On cabotage as a mere technique of navigation see X. Nieto, 'Le commerce de cabotage et de redistribution', in P.A. Gianfrotta et al., eds., La navigation dans l'Antiquité (Aix-enProvence 1997), 146-159.

15 Act.Ap. 27.1-28.5.

16 Paul is said to have suggested, contrary to the judgment of the pilot and the ship-owner, that the season was not appropriate for sailing, the day of atonement having already
} 
storm and shipwreck occurred. Much of Paul's journey as it is described up to this point matches the fundamental characteristics of cabotage, quite regardless of the nature of the various harbours of departure, the size of the ship employed, and the planned routes. Time and again, the journey, undertaken mostly along the coast, encounters challenging weather, which necessitates a variety of improvised measures, including updating planned routes, anchoring in inappropriate or unsafe harbours, and sailing beyond the dates of the customary sailing season.

\section{4}

\section{The Southern Levant}

The challenges with which Paul's journey was faced, still before the shipwreck itself took place, would have comprised a significant part of the sailing routine in the ancient Mediterranean. But we must pay attention here not only to the difficulties imposed by weather, but also, and perhaps more crucially, to the tribulations caused by the system itself. If a significant part of the volume of maritime activity in antiquity may be ascribed to coastal skirting, then not only trade, but travel itself, must be imagined to have been embedded within this particular sphere. What exactly did it imply to coast-skirt around the Mediterranean?

In a catalogue of ancient Mediterranean shipwrecks, compiled in 1992, more than 1,200 items were documented-some of which were excavated thoroughly while others were only superficially surveyed. ${ }^{17}$ Today, the number of known shipwrecks for the Mediterranean in its entirety must exceed 2,00o, and an update for Parker's catalogue would be most welcome. While finds of shipwrecks are usually locally contextualized, the magnitude of the numbers has occasioned the emergence of generalisations on a broader scale. ${ }^{18}$

Most relevant to our discussion here, the majority of shipwrecks dated to antiquity may be considered small or medium in size. ${ }^{19}$ While the average

passed (Act.Ap. 27.9-11). For the sailing season see also Ph. Post. Cain. 7.22; Leg. ad Gaium 3.15. Philo shows himself aware of the dangers of sailing beyond "the beginning of Autumn", yet he sails with his delegation to meet Caligula in mid-winter.

A.J. Parker, Ancient Shipwrecks of the Mediterranean and the Roman Provinces (Oxford 1992).

18 E.g. M. Jurisic, Ancient Shipwrecks of the Adriatic (Oxford 2000). For the development of maritime archaeology more generally, and current approaches to the research of shipwrecks, see D. Gibbins and J. Adams, 'Shipwrecks and maritime archaeology', World Archaeology 32.3 (2001), 283-287.

Woolf 2016, op. cit. (n. 2), 461-462. 
tonnage of Mediterranean ships rises and drops during certain periods in antiquity, it remains in the area of several dozens tons, and never soars to represent a significant shift towards larger ships. ${ }^{20}$ Papyri from Egypt support this picture. The Customs Account, discovered under an Aramaic text from Elephantine, contains a list of 42 ships - 36 Ionian Greek and 6 Phoenicianimporting in the year $475 \mathrm{BC}$ a variety of goods to a harbour in the Nile Delta, from where they exported, all without exception, mineral soda for the textile industry. ${ }^{21}$ Most of the ships on the list are estimated to have been small, which prompts Horden and Purcell to identify them as acting within the sphere of cabotage, despite the high value of their cargo, and our lack of knowledge regarding the actual routes they had taken on their way to and from Egypt. ${ }^{22}$ Another example, the famous P. Bingen 77, includes a shorter list of 12 ships, arriving in an unspecified harbour in the Nile Delta sometime in the second century AD. ${ }^{23}$ Here the tonnage for nine ships is mentioned in units of artaba, and, save one large vessel hailing from Ostia, all may be considered small or medium in size. ${ }^{24}$

Let us turn our focus to Paul's customary area of departure, the south-eastern corner of the Mediterranean, and to its respective maritime heritage. Firstly, it must be noted that the shores of the Southern Levant are unanimously considered to have been challenging to pre-modern seafarers. The reasons for this are varied, and include the dominant western vector of local winds, and the paucity of natural harbours along the coastline. Local ancient societies were

20 E. Nantet, Le Tonnage des navires de commerce en Méditerranée du VIIIe siècle av. l’è. chr. au VIIe siècle de l'è. chr. (Rennes 2016). See also D. Rathbone, 'The financing of maritime commerce in the Roman Empire, I-II AD', in E. Lo Cascio, ed., Credito e moneta nel mondo romano (Bari 2003), 210-225; A. Tchernia, 'L'utilisation des gros tonnages', in W.V. Harris and K. Iara, eds., Maritime Technology in the Ancient Economy: Ship-Design and Navigation (Portsmouth 2011), 83-88.

21 B. Porten and A. Yardeni, Textbook of Aramaic Documents from Ancient Egypt, vol. 3, Literature, Acounts, Lists (Jerusalem 1993), §C3.7.

22 O. Tal, 'On the identification of the ships of $K Z D / R Y$ in the erased customs account from Elephantine', Journal of Near Eastern Studies 68.1 (2009), 1-8; P. Briant and R. Descat, 'Un registre douanier de la satrapie d'Égypte à l'époque achéménide', in N. Grimal and B. Menu, eds., Le commerce en Égypte ancienne (Paris 1998), 59-104; Horden and Purcell 2000, op. cit. (n. 1), 149.

23 P. Heilporn, 'Registre de navires marchands', in J. Melaerts, ed., Papyri in honorem Johannes Bingen octogenarii (Leuven 2000), 339-359.

24 Arnaud 2005, op. cit. (n. 13), 35. 
well aware of the challenging characteristics of the shoreline, as indicated by Josephus' report: ${ }^{25}$

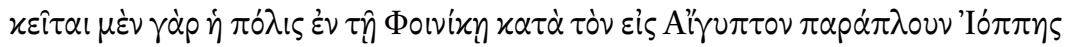

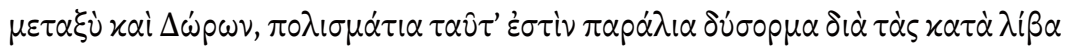

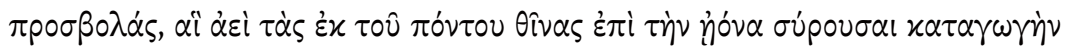

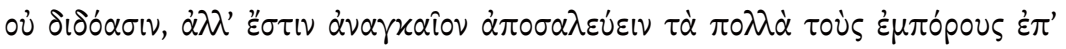
àrúpas.

This city [i.e. Strato's Tower] is situated in Phoenicia, on the sailing route to Egypt, between Joppa and Dora, which are coastal towns with inappropriate anchorage, on account of the attacks of the winds upon them, which, dragging the sand from the sea to the shore, do not allow the landing of ships, and the merchants are forced for the most part to anchor in the open sea.

Nevertheless, the challenging nature of the coast need not indicate that maritime activity in the area was less intense than in other stretches of Mediterranean shores. By the early 1990 os some thirty shipwrecks were recorded along the shores of the Southern Levant. And since the publication of the shipwreck catalogue, underwater work has resulted in the discovery and careful study of more than a dozen additional shipwrecks. The total of the finds, then, may be taken to represent the current picture of shipwreck archaeology in Israel. It is presented in Table 1, broken up into rough periodization. ${ }^{26}$

It is not a straightforward task to learn from this corpus more about options of mobility for locals and visitors during antiquity. Travelers left almost no trace in the archaeological record, and the written reports are significantly more reticent about the actual technicalities of travelling than they are on shipwrecking. From the silence of such sources as the Rhodian Sea Law, we

25 J. AJ 15.333. For a survey of the geography of the area and changes in its coastline see A. Raban, 'The heritage of ancient harbor engineering in Cyprus and the Levant', in V. Karageorghis and D. Michaelides, eds., Proceedings of the International Symposium Cyprus and the Sea (Nicosia 1995), 139-141.

26 See Table 1. The shipwrecks that were discovered until 1992 are documented in Parker 1992, op. cit. (n. 17), nos.: 1; 2; 3; 26; 27; 61; 136; 137; 138; 367; 494; 495; 503; 504; 505; 525; 540; 541; 612; 689; 690; 697; 700; 739; 740; 741; 809; 1069; 1078; 1115. For shipwrecks excavated since 1992 see below. 
may deduce that travellers played a lesser part in the maritime sphere than commercial cargo, at least as far as the official authorities were concerned. ${ }^{27}$

Indeed, in a great number of cases where passengers are referred to in the official legislation, they are specified to be merchants travelling with their merchandise, and sharing in the responsibilities for the handling of the cargo and the ship's welfare. In one place in the Rhodian Sea Law, the captain is to consult merchants with goods on board should the need for jettison arise; an ultimate decision is made by the vote of all merchants on board. Another reference to the topic discloses the mutual responsibility of captain and merchant for compensation in the case of the loss of a ship. ${ }^{28}$ One is reminded of Paul's plea to the captain not to continue the voyage on account of the late

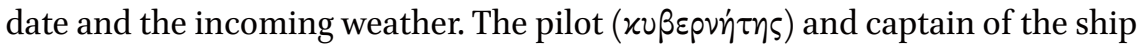

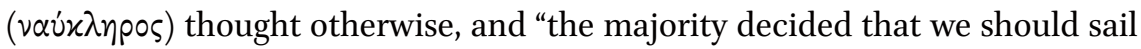
on."29 The group that voted must have consisted of merchants travelling with their cargo, the same cargo that soon would be thrown overboard with the rise of the tempest.

Perhaps surprisingly, we do not find too much evidence for shipwrecks in Caesarea-the reported point of departure for some of the more famous individuals of the period, among them Herod, Paul, and Josephus. But here is the point to wonder about the actual significance of the size and sophistication of the harbour of Sebastos at Caesarea for the topic of individual mobility. If most of the options that were available for sea-bound travellers relied on smaller, coast-skirting vessels, then Caesarea's glamorous advantages would have been rendered irrelevant, and the gigantic artificial harbour may have been considered as just another anchoring possibility among a variety of smaller harbours and natural anchorages located along the coasts of the Southern Levant. The

27 Greg Woolf estimates - very provisionally — that in any given year only one person in a thousand travelled over long distances. See Woolf 2016, op. cit. (n. 2), 462.

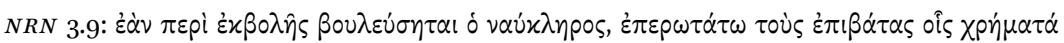
$\dot{\varepsilon} \sigma \tau \imath \nu \dot{\varepsilon} \nu \tau \hat{\omega} \pi \lambda \circ i \omega$. jettison, let him consult the passengers who have goods on board; and let them put it to

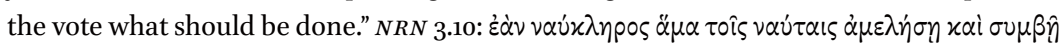

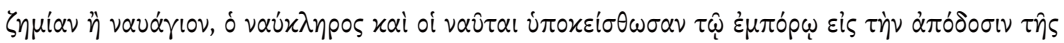

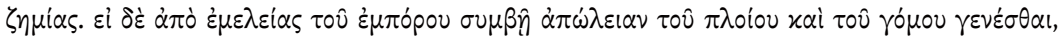

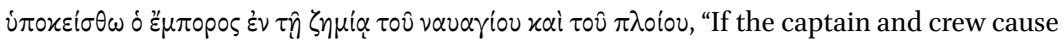
damage or shipwreck out of neglect, let the captain and crew be responsible to the merchant for covering the damage. If it is as a result of the merchant's negligence that the ship and the cargo are destroyed, let the merchant be responsible for the damage caused by the shipwreck."

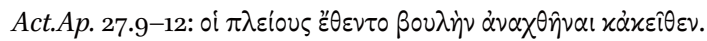


fact that Sebastos would have been a lively hub of transportation on account of its size and centrality, while it would have served as an advantage for some ship-owners and travellers, could just as well have been an impediment and a hindrance to others-finding, perhaps, such centrality less affordable, or too closely regulated by the authorities. ${ }^{30}$

\section{$5 \quad$ Dor}

The city of Dor, located only $15 \mathrm{~km}$ to the north of Caesarea, serves as an important source of information in this investigation, having along its shores several bays and lagoons that would have served as natural anchorages to smaller vessels, and offering abundant evidence of shipwrecks. ${ }^{31}$ In preliminary surveys undertaken in a lagoon located to the south of the Tel, several sites were marked as potentially hosting a shipwreck. ${ }^{32}$ The lagoon, it should be highlighted, shows no indication of port facilities. Systematic work was begun later in the 199os to excavate and document as many of the shipwrecks of the lagoon as possible. It is a remarkable fact that seven of the shipwrecks that have been carefully studied so far have been dated to a period loosely matching that of Late Antiquity. Indeed, of the dozen shipwrecks excavated since the early 1990s, these seven are the only representatives of antiquity. ${ }^{33}$

Generalising from this group should be approached with caution, since there is much about them that remains unknown. Still, it may be said that the size of these ships ranges from small to medium, and their capacity may reach

30 The much neglected southern bay of Caesarea is another case in point, as there are indications that it served maritime needs at the same time as Sebastos, much in the way Dor did. For now all that was published on the site may be found in E. Galili, U. Dahari and J. Sharvit, 'Underwater surveys and rescue excavations along the Israeli coast', The International Journal of Nautical Archaeology 22 (1993), 65-69.

31 For an initial summary of the results of surveys conducted in the area of Dor between 1976 and 1991 see S.A. Kingsley and K. Raveh, The Ancient Harbour and Anchorage at Dor, Israel (Oxford 1996); see also a review by Bass: G.F. Bass, 'Review: Sean A. Kingsley and Kurt Raveh, The Ancient Harbour and Anchorage at Dor, Israel', Biblical Archaeologist 60 (1997), 57.

32 Kingsley and Raveh 1996, op. cit. (n. 31), 55-75. See map of Dor below.

33 See Table 2. The shipwrecks—all but Dor 2006 - are presented en masse and discussed from a technological point of view by Y. Kahanov, 'Ancient shipwrecks in the lagoon of Dor (Tantura) and their meaning' (Heb.), Katedra 134 (2010), 6-24; see also Y. Kahanov, 'Ship reconstruction, documentation and in situ recording', in A. Catsambis, B. Ford and D.L. Hamilton, eds., The Oxford Handbook of Maritime Archaeology (Oxford 2011), 169-181. 
as high as a few dozen tons. All of the ships could navigate in shallow waters, which made lagoons and natural anchorages viable anchoring locations. This would have made all of them suitable for improvised coastal activity.

Almost none of these ships yielded clear indication regarding their cargo. They could of course have foundered empty; or the goods on board could have been carried by currents or perished in the run of time. Salvaging, though, was common enough in antiquity, and well-supported by particular legislation. The Rhodian Sea Law goes as far as to enumerate the reward owed to salvours who abide by the law. The closeness of most of the shipwrecks to the shore makes this option the one most likely to have taken place. ${ }^{34}$

The reason for the presence of these ships in Dor's lagoon is still a debated issue. ${ }^{35}$ The difficulty arises from archaeological and literary evidence, testifying to the sudden disappearance of Dor from the map of local coastal settlements by the middle of the third century. The archaeological and literary records are unequivocal about the complete cessation of activity on the Tel by the middle of the third century. ${ }^{36}$ The last coins known to have been minted at Dor are from the Severan period. ${ }^{37}$ It is possible, however, that a smaller, more modest version of the settlement continued to exist on the eastern slopes of the Tel. ${ }^{38}$ And on the same slopes a large Christian basilica was discovered, which was built in the middle of the fourth century, and served as the local episcopal seat well into the Muslim period. ${ }^{39}$ The importance of the basilica in the local scene cannot be overlooked, and is evidenced by its monumental size, and the fact that it served as a xenodocheion..$^{40}$ It also hosted two graves of

$34 \quad N R N$ e.g. 45-47. An exhaustive discussion of primary sources on the topic may be found in the introduction of Ashburner 1909, op. cit. (n. 11), cclxxxviii-ccxciii.

35 G. Gambash, 'Maritime activity in the ancient southern Levant: The case of Late Antique Dor', ARAM 27 (2015), 61-74.

36 E. Stern, Dor: Ruler of the Seas (Jerusalem 1994), 319-323. See also Eus. Onom. under Dor

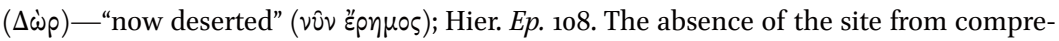
hensive surveys of the area is also telling, e.g. the Bordeaux Pilgrim 585; Al-Muqaddasi (trans. G. le Strange), Description of Syria, Including Palestine (London 1886), 12-65 (particularly pp. 53-55).

37 Israel Numismatic Journal 9 (1986-7), no. 44 (Julia Domna); and no. 52 (Plautilla).

38 C. Dauphin and S. Gibson, 'The Byzantine city of Dor/Dora discovered', Bulletin of the Anglo-Israel Archaeological Society 14 (1994), 9-38.

39 C. Dauphin, 'On the pilgrim's way to the holy city of Jerusalem: The basilica of Dor in Israel', in J.R. Bartlett, ed., Archaeology and Biblical Interpretation (London 1997), 145-165.

40 For the topic, see O.R. Constable, Housing the Stranger in the Mediterranean World (Cambridge 2006). 
saints, and sacred relics from Golgotha, and we must assume that it appeared on such pilgrimage maps as the fragmental one discovered at Madaba. ${ }^{41}$

There is, however, a major problem in ascribing the presence of ships in late antique Dor to the pilgrimage movement. The mere economy of the ship trade probably would not have allowed revenues based on taxi services alone to support the costs of a sea voyage, let alone produce profit to ship owners. Contemporary documentation sheds light on the extent to which ship owners relied for profit on the transportation of goods. The Rhodian Sea Law, as shown above, concentrates almost exclusively on issues of profit from trade, while referring to passengers mostly under their capacity as tradesmen travelling with their merchandise. It could, for example, offer solutions to the common enough situation of passengers who did not make it to their intended destination, and to the question of compensation in such cases.

It may, however, prove fruitful to turn our gaze towards Dor's immediate hinterland, and to note the vibrant commercial activity that was conducted there, and that would have made good use of Dor's natural anchorages. For the Byzantine period, more than a hundred sites indicate activity in Dor's immediate surroundings alone. ${ }^{42}$ And during the early Muslim period, though economic activity as well as population size dwindled dramatically, the Dor area nevertheless remained populated and active, and contemporary archaeological finds, consisting mostly of pottery and buildings, have been discovered in more than a dozen sites. ${ }^{43}$ One major focus of activity would have been a Muslim fortress, built in Kafr Lam soon after the Arab conquest. ${ }^{44}$

The shipwrecks of Dor suggest that coastal trade routes along the Southern Levant remained open and active regardless of the shifting political and economic circumstances. Dor's southern lagoon was hardly an ideal docking spot, yet it was one that complied in nature with the period's seafaring activity across the Mediterranean, consisting for the most part of smaller ships, regularly occupied in coastal activity. And, of course, it is not Dor alone that is the issue here, rich in shipwrecks as the site may be. Shipwrecks from the Byzantine period, for example, were also discovered in Hof Hakarmel, Sdot

41 For the holy graves see Dauphin 1997, op. cit. (n. 39), 160. For the relics of Golgotha see CIIP 2117 (pres. loc.: Israel Museum, Jerusalem, IAA inv. No. 1952-1153). For the Madaba Map see H. Donner, Die Mosaikkarte von Madeba (Wiesbaden 1977).

42 J. Olami, S. Sender, and E. Oren, Map of Dor (30) (Heb.), (Jerusalem 2005).

43 For economic and demographic decline see C. Dauphin, La Palestine byzantine: peuplement et populations, vol. I, (Oxford 1998), 349-525. For populated sites in the area see Olami, Sender and Oren 2005, op. cit. (n. 42). 
Yam, Newe Yam, and Mikhmoret. ${ }^{45}$ Now that we know of the ships from Dor there is no reason to think that the shores of the Southern Levant did not witness maritime activity during the early Muslim period. ${ }^{46}$ Dor's uniqueness, as far as this research is concerned, lies in the relatively large number of ships that foundered in its southern lagoon during Late Antiquity.

It would have been sites such as Dor's lagoon, and ships similar to the ones that were wrecked in it, that would have represented travelling in the ancient Mediterranean in its most commonly available form. Indeed, it remains highly debatable whether larger ships frequented the shores of the Southern Levant in significant numbers at all. More than a few hypotheses have been suggested for explaining the building of the massive artificial harbour of Sebastos at Caesarea. ${ }^{47}$ One such hypothesis relates to the large freighters, known to have served the grain demands of Rome on the line between Alexandria and Italy. There are significant problems in ascribing central planning to the institution of the annona. Here too market forces of demand can be seen as the main motivators behind the significant efforts witnessed all around the Mediterranean to bring grain in sufficient amount to Rome. The proponents of a grand strategic organization of the annona assume, however, that the central government-Augustus and Agrippa themselves, in our case-was involved in facilitating the grain flow. ${ }^{48}$ The harbour at Caesarea, according to this hypothesis, was conceived and built in order to supply another stop on the way from Alexandria to Syria, notorious for its lack of harbours and natural havens.

The question to be asked here is to what extent the grain freighters, which often took sea-crossing routes, actually required frequent stops, or at least immediate possibilities for security, in the case of bad weather. The text of Lucian of Samosata, quoted above, offers revealing details regarding the route preferred by one of the few skippers whose voice is heard in the sources. Before losing its course, it is stated in the dialogue, the ship initially made

45 Parker 1992, op. cit. (n. 17): Hof Hakarmel, no. 505; Sdot Yam, no. 1069; Newe Yam, no. 740; Mikhmoret, no. 697 .

46 It would have been tempting to assume, prior to the recent excavations, that the volume of maritime traffic in the southern Levant during the early Muslim period was meagre.

47 G. Gambash, 'Caesarea Maritima and the grand strategy of the Roman Empire', Skyllis 13.1 (2013), 53-58.

48 For discussion see e.g. H.K. Beebe, 'Caesarea Maritima: its strategic and political significance to Rome',Journal of Near Eastern Studies 42.3 (1984), 195-207; G.E. Rickman, 'Towards a study of Roman ports', in A. Raban, ed., Harbour Archaeology (Oxford 1985), 105-114; A. Raban, The Harbour of Sebastos (Caesarea Maritima) in its Roman Mediterranean Context (Oxford 2009), 1-13. 
it, with a moderate wind, from Alexandria to Cyprus - to Akamas, the cape at the northwest extremity of the island. The journey lasted seven days, and this amount of time indicates beyond doubt that the ship sailed on a direct course, through the open sea, and not, as is usually assumed for ships leaving Alexandria, along the shores of the Levant. ${ }^{49}$

The reality described in Lucian's dialogue, written around the year 150, may be seen to represent the first and second centuries $\mathrm{AD}$, when the traffic of the grain freighters was at its height. It is hard to imagine what role the harbour of Caesarea would have played in such a routine, 'cutting the corner'-so to speak - of the entire eastern-Mediterranean coast in favour of a shorter, faster route to Rome. If that was the habit of most Alexandrian freighters, the traffic of larger ships along the coasts of the Southern Levant would have been significantly scarcer than current estimations suggest.

\section{Conclusion}

This article opened in pointing out the pronounced parallelisation that prevails in current scholarship between connectivity and mobility. It was then suggested that many of the difficulties usually ascribed to sea-voyages in antiquity are outlined in light of the physical dangers therein. It is the combination of both that prevents a more accurate evaluation of the difficulties presented to the average ancient traveller, not by bad weather, but by the versatile structure of the system, based as it was on the improvised and arbitrary movement of those main vehicles of transportation-the vessels of cabotage.

The great majority of travel reports from antiquity are supplied in the form of itineraries, simply indicating points of departure and arrival. ${ }^{50}$ In order to introduce some nuance to these reports, and learn about the technicalities of such journeys - going beyond the odd event of unwelcoming weather-we must look carefully for evidence that breaks up the journey into finer details. In the case of Paul, who is believed to have travelled 10,00o miles around the Mediterranean before being transported to Rome, it is the very broken nature

49 Calculations suggest that the direct route to Cyprus would have taken five days at the minimum; whereas sailing along the Levantine coast would have lasted no less than two weeks, and that while sailing also during nighttime. The calculations are based on W. Scheidel and E. Meeks, ORBIS: The Stanford Geospatial Network Model of the Roman World (http://orbis.stanford.edu). 
of the journey that sheds revealing light on the process. ${ }^{51}$ When returning, for example, from Miletus to Caesarea, Paul first had to sail to Kos, and on the next day continued from there to Rhodes and then to Patara. In Patara he found a ship that took him to Syria via Cyprus. This ship was to unload its cargo in Tyre, and Paul stayed in the city for a week before continuing his journey, to Ptolemais, and from there, after another break, to Caesarea.

Even when sent from Caesarea by the Roman governor of Judea to stand trial in Rome, Paul was forced to make his way in sections. All that was managed for the transportation of the prisoner-in all the glorified harbour of Caesareawas a ship of Adramytium, which was headed to "places along the coast of Asia." 52 The ship probably belonged to the smaller category of coast-skirting vessels, such as the ones discovered in Dor. It stopped in Sidon, and continued via Cyprus to Asia Minor. Only in Myra was the centurion escorting Paul able to find a ship headed for Rome. Such would have been the tribulations of travelling by sea in antiquity. Most assuredly, any individual would have found it possible to make his or her way from point A to point B almost anywhere across the Mediterranean. The infrastructure of connectivity, consisting in dense networks of maritime movement of all sorts-but perhaps of cabotage above all —would have warranted the viability of every such trip, just as it would the circulation of news and the dissemination of knowledge, the redistribution of surpluses and, basically, the usually successful matchmaking between demand and supply. But, while connectivity would have guaranteed communications, the spread of new technologies, or the consumption of anything from luxuries to locally unavailable necessities, it did not correspond to the extensive, omnipresent movement of individuals. For mobility, connectivity merely served as potential only occasionally—or, indeed, almost seldom—realised.

Haifa, December 2015

51 W.A. Meeks, The First Urban Christians: The Social World of the Apostle Paul (New Haven and London 1983), 16.

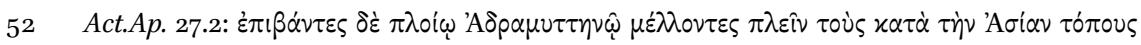
$\dot{\alpha} \nu \eta \dot{\chi} \chi \emptyset \eta \mu v$. 


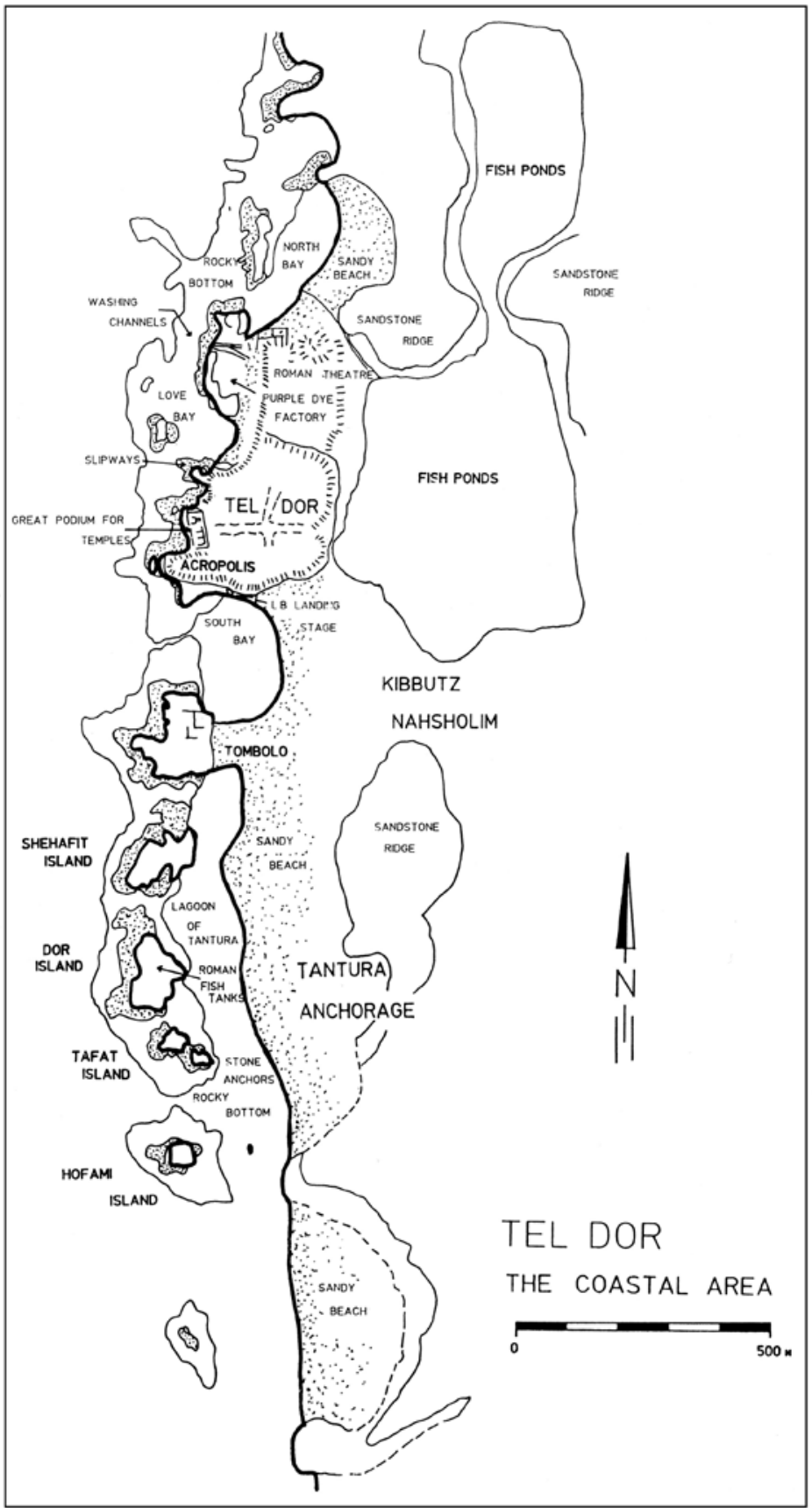

MAP 9.1 A plan of Tel Dor, its bays, and the Tantura lagoon. After

A. Raban, 'The Harbour of the Sea Peoples at Dor', The Biblical Archaeologist 50.2 (1987), 118-126. 
TABLE 9.1 Shipwreck archaeology in Israel differentiated chronologically in number of shipwrecks found $(N=44)$

\begin{tabular}{lclc}
\hline Date (centuries) & Discovered up to 1992 & Discovered since 1992 & Current Total \\
\hline M B & 1 & - & 1 \\
LB & 3 & - & 3 \\
Iron & 1 & 2 & 3 \\
$6-4$ BC & 6 & - & 6 \\
$3-1$ BC & 5 & - & 5 \\
$1-3$ & 6 & - & 6 \\
$4-6$ & 5 & 3 (Dor) & 8 \\
$7-9$ & 1 & 4 (Dor) & 5 \\
Later & 3 & 4 & 7 \\
Totals & $\mathbf{3 1}$ & $\mathbf{1 3}$ & 44 \\
\end{tabular}

TABLE 9.2 The late antique shipwrecks of Dor

\begin{tabular}{|c|c|c|c|c|}
\hline & $\begin{array}{l}\text { Date } \\
\text { (century AD) }\end{array}$ & Size & $\begin{array}{l}\text { Building } \\
\text { Technique }\end{array}$ & Cargo \\
\hline Dor D & mid 4-early 7 & Medium? & Shell based & Personal \\
\hline Tantura A & late 5 -early 6 & Small & Frame based & Personal \\
\hline Dor $2001 / 1$ & early 6 & $17 \cdot 5 \mathrm{~m}$ & Frame based & $\begin{array}{l}\text { Personal + } \\
\text { Building Blocks? }\end{array}$ \\
\hline Dor 2006 & $5^{-6}$ & Medium? & Frame based & Personal \\
\hline Tantura F & mid 7 -late 8 & $16 \mathrm{~m}$ & Frame based & $\begin{array}{l}\text { Personal + Fish } \\
\text { Products? }\end{array}$ \\
\hline Tantura E & $7-9$ & $?$ & Frame based & Personal \\
\hline Tantura B & early 9 & $18-23 \mathrm{~m}$ & Frame based & Personal \\
\hline
\end{tabular}

